\title{
Mapping mountain areas: learning from Global, European and Norwegian perspectives
}

\author{
Martin F. PRICE1* (iD http://orcid.org/oooo-0oo2-7430-7262; ${ }^{\star}$ e-mail: martin.price@perth.uhi.ac.uk \\ Tor ARNESEN2 (D)http://orcid.org/oooo-0003-4803-0682; e-mail: tor.arnesen@ostforsk.no \\ Erik GLØERSEN3 iDhttp://orcid.org/oooo-ooo3-1200-3543; e-mail: erik.gloersen@spatialforesight.eu \\ Marc J. METZGER4 iDhttp://orcid.org/oooo-0oo2-5119-5894; e-mail: marc.metzger@ed.ac.uk \\ * Corresponding author \\ 1 Centre for Mountain Studies, Perth College, University of the Highlands and Islands, Crieff Road, Perth PH1 2NX, \\ United Kingdom \\ 2 Mountain Research Programme, Eastern Norway Research Institute, 2600 Lillehammer, Norway \\ 3 Spatial Foresight, Territorial Policy Support and Research, 75013 Paris, France \\ 4 Research Institute of Geography and the Lived Environment, School of GeoSciences, University of Edinburgh, \\ Edinburgh EH8 9XP, United Kingdom
}

Citation: Price MF, Arnesen T, Gløersen E, et al. (2018) Mapping mountain areas: learning from Global, European and Norwegian perspectives. Journal of Mountain Science 16(1). https://doi.org/10.1007/s11629-018-4916-3

(C) The Author(s) 2018, corrected publication 01/2019

\begin{abstract}
Defining the spatial extent of mountain areas has long been a challenge. In the present century, the availability of digital elevation models (DEMs) incorporated into geographic information systems (GIS) has allowed the definition of mountain areas based on topographic and other criteria. This paper presents the various delineations of mountains that have been prepared at three scales - global, regional (Europe), and national - and explores the reasons and processes leading to these delineations, and how they have been used. A detailed case study is then presented for Norway. Overall, two types of approaches to mapping mountains have been taken: first, considering mountains per se, based on elevation and/or topography; second, considering them among other categories, e.g., landforms or biogeographical, environmental or landscape zones. All attempts to map mountain areas derive essentially from the objectives of those commissioning and/or undertaking the work; a unitary definition remains unlikely.
\end{abstract}

Received: 06 March 2018

Revised: 23 April 2018

Accepted: 27 April 2018
Keywords: Mountains; Mapping; Geographic information systems Europe; Norway; Topography

\section{Introduction}

Twenty-six years ago, at the 1992 United Nations Conference on Environment and Development, or 'Earth Summit', mountains were accorded a chapter in the final outcome document, 'Agenda 21'. This represented a success for a diverse group of stakeholders to give global prominence to the importance of mountain areas in the context of sustainable development (Debarbieux and Price 2008). Following the achievement of this initial goal, mountains have remained on the global agenda (Debarbieux and Rudaz 2015; United Nations 2016). One key argument for this global attention to mountains is that they cover a significant proportion of the Earth's land surface. In 1992, this was estimated as about 20 percent (Felber 1992). This "long- 
standing guesstimate" (cf. Louis 1975) was again referred to in a state-of-knowledge book on the world's mountains in 1997, with a comment that "the search for a unitary definition of mountain is to chase a chimera" (Ives et al. 1997: 8). A subsequent paper asked, "Do mountains exist?", and stated that, while the summits and upper slopes of mountains have "determinate, prominent, and crisp" boundaries, "as we proceed downwards towards the foot of the mountain, no single candidate boundary is distinguishable at all" (Smith and Mark 2003: 412).

Nevertheless, as discussed in this paper, over the past two decades, geographic information systems (GIS) have been used to identify the boundaries of mountain areas, and thus produce more precise estimates of their spatial extent, both globally and in various parts of the world. There are at least three reasons for delineating the area of mountains. Two of these were recognised by Smith and Mark (2003: 420): as landforms whose identification, as geographic objects, can be used to support environmental modelling; and in relation to "politico-administrative processes". The first of these can be widened to include the characterisation of mountains with regard to biophysical and even socio-economic criteria. As can be seen from the process of generating and maintaining attention to mountain issues described above, a third argument is as a basis for advocacy, policy-making or collective action (Rudaz 2009; Debarbieux et al. 2014). With this background, this paper has two aims. First, to present the various delineations of mountains that have emerged during the present century at three scales - global, regional (Europe), and national and explore the reasons and processes which led to these delineations and how they have been used. Second, to analyse the processes that led to the delineation of mountains for Norway, a country which most people would regard as largely mountainous but where a specific set of nationally relevant criteria have been developed for domestic regional policy reasons.

\section{Global Experiences}

The Oxford English Dictionary (2018) defines a mountain as a "large natural elevation of the earth's surface, esp. one high and steep in form (larger and higher than a hill) and with a summit of relatively small area". Thus, two topographic criteria are indispensable in identifying mountains: elevation and steepness. Nevertheless, as various authors have noted, geographic features which have locally been named as 'mountain' may not be particularly high - such as Iron Mountain, Florida (100 meters above sea level, masl) and Vaalserberg in the Netherlands (323 masl) - and steepness is a characteristic of canyons as well as mountains (Byers et al. 2013; Price 2015). A further criterion is therefore required to delineate the area of mountains: terrain roughness or local elevation range (LER) - and, in the 1990s, the advent of global digital elevation models (DEMs) made this possible.

The first global map of mountains using this approach was published in 2000 , as a by-product of a project to produce a map of global mountain forests to accompany a state-of-knowledge report on forests in sustainable mountain development (Price and Butt 2000). While a global map of forest types was already available, a mountain layer was needed so that this could be overlain with this existing map in order to show the distribution of mountain forests. Kapos et al. (2000), in consultation with scientists, policymakers and mountaineers from around the world, produced this mountain layer starting from first principles, by iteratively combining parameters from a global DEM with a spatial resolution of 30 arc seconds (c. $1 \mathrm{~km}^{2}$ ). Every grid cell above 2500 masl, the threshold above which human physiology is affected by oxygen depletion, was considered 'mountain', and all land below 300 masl was considered as non-mountainous. At elevations from 1000 to 2500 masl, slope thresholds of increasing steepness with decreasing elevation were used. For grid cells between 300 and 1000 masl, the LER was evaluated for a 7 - $\mathrm{km}$ radius around each cell: If the LER was at least $300 \mathrm{~m}$, the cell was defined as 'mountain.' According to this typology, 24 percent of global land area was classified as 'mountain'. This map, and the related statistic, have subsequently been used as the basis for many other global studies (e.g., Debarbieux et al. 2000; Meybeck et al. 2001; UNESCO 2001; Blyth et al. 2002; Huddleston et al. 2003; Rodríguez-Rodríguez et al. 2011; Rodríguez- 
Rodríguez and Bomhard 2012; Romeo et al. 2015) and in numerous publications arguing for the importance of policies targeted to the needs of mountain areas (e.g., Mountain Agenda 2002; Ariza et al. 2013; Kohler et al. 2014; von Dach et al. 2016).

Despite the widespread use of the delineation of mountains produced by Kapos et al. (2000), the ecologists of the Global Mountain Biodiversity Assessment (GMBA) network have argued that the criteria on which it is based are too broad, particularly for research on biodiversity and biogeography, so that a global delineation based purely on ruggedness (i.e., LER) is needed (Körner et al. 2011). The most recent version was published by Körner et al. (2016). This has a finer spatial resolution (2.5') than that of Kapos et al. (2000), and applies an LER of $200 \mathrm{~m}$ across $9(3 \times 3)$ grid points of 30 " within each grid cell (pixel). The resulting map delineates 12 percent of global land area as mountainous; this includes the rugged parts of the Tibetan plateau and the Andean altiplano, both above 2500 masl, but not significant areas of low-elevation mountains with elevations from 300 to 1000 masl identified by Kapos et al. (2000) - though it does include some areas below 300 masl. The underlying database forms the foundation for a global inventory of mountain areas and their biodiversity (http://www.mountainbiodiversity.org) which is being used as the basis for research (e.g., Nürk et al. 2018).

In addition to these two maps which focus only on mountains, two recent global maps identify mountains as specific landforms (Sayre et al. 2014; Karagulle et al. 2017). The former map, commissioned by the inter-governmental Group on Earth Observations (GEO), is at a spatial resolution of $250 \mathrm{~m}$ : pixels with a slope of $>8 \%$ and relative relief of 91- $400 \mathrm{~m}$ are identified as low mountains, and those with a relative relief $>400 \mathrm{~m}$ as high mountains. Landforms are only one of the four layers of this map; the others represent bioclimate, lithology, and land cover. The four layers are overlain to create of ecological land units (ELUs) with many anticipated uses, such as the assessment of ecosystem services and of climate change and its impacts, and setting priorities for biodiversity conservation. The map developed by Karagulle et al. (2017) also has a spatial resolution of 250m, and identifies four mountain classes: low mountains; scattered low mountains; high mountains; and scattered high mountains. Together, the former two classes cover 27 percent of the Earth's land surface; the two latter cover 9 percent. The authors note that they are using the outputs to characterize ecologically distinct areas, and envisage other uses such as the assessment of agricultural productivity or of disease vectors across landscapes.

In summary, there are currently four global delineations of mountain area. The 'Global Mountain Explorer' website (https://rmgsc.cr.usgs. gov/gme) now allows comparison of three of these: Kapos et al. (2000), Körner et al. (2016), and Karagulle et al. (2017). One of these delineations was produced incidentally; the others were developed primarily for ecological purposes. However, the first (Kapos et al. 2000) has also been used for ecological analyses (e.g., Blyth et al. 2002; Rodríguez-Rodríguez et al. 2011; RodríguezRodríguez and Bomhard 2012) and many other purposes. Two key reasons for this are that it was the first, appearing shortly before the International Year of Mountains 2002, for which many studies and reports were prepared; and its production was funded by the Swiss Agency for Development and Cooperation, a major player in global initiatives supporting sustainable mountain development (Kohler et al. 2001; Debarbieux and Rudaz 2015). In this context, a key concern has been the number of people living in mountain areas, addressed by Meybeck et al. (2001), Huddleston et al. (2003) and Romeo et al. (2015) who, using the same methodology as Kapos et al. (2000) but taking into consideration improvements in the resolution and accuracy of remote sensing models, recalculated that mountains occupy 22 percent of global land area, with 915 million inhabitants (13 percent of the global population). Körner et al. (2017) calculated comparable statistics, and found that the smaller proportion of global land area they defined as 'mountain' was home to 386 million people (5 percent). For those arguing for the importance of attention to mountains in the context of sustainable development, the former statistics are undoubtedly of greater value; it may be noted that the studies by Huddleston et al. (2003) and Romeo et al. (2015) were both undertaken by the Food and Agriculture Organisation (FAO), the United Nations lead agency for mountains. 


\section{European Experiences}

In Europe, the first delineations of mountain area were included in national laws and policies in the Alpine countries of Austria, France, Italy and Switzerland from the late 1920 s to the 1960 s (Debarbieux et al. 2013). These mainly resulted from the lobbying of mountain farmers, who noted the particular constraints of mountain agriculture and the consequent need for financial support. These and other national delineations (Castelein et al. 2006) have all used elevation as a criterion, sometimes in combination with other criteria such as slope and LER. For the purposes of applying the laws and policies, these criteria are applied to municipalities: at least a minimum proportion of their area has to meet the criteria to be identified as 'mountain'. For example, in Italy, at least 80 percent of a municipality's area has to be $>600$ masl to be considered as 'mountain'.

In 1975, similar actors and arguments led to the only European Union (EU) legislation that refers to specifically mountain areas: the Less Favoured Area (LFA) Regulation, which aimed to provide subsidies to support farmers whose production and competiveness were limited by socalled 'natural handicaps'. However, the EU left its Member States to define the criteria and thus the specific areas to which the relevant article of this regulation applied; those states that did so all specified a minimum altitude and, in some cases, also other criteria (Nordregio 2004; Gloersen 2012).

As the EU grew, cohesion policy, which aims to reduce economic and social disparities across the $\mathrm{EU}$, became an increasing imperative (Bunazzo 2016), particularly with the accession of 10 new Member States in 2004. Many of these (Cyprus, Czech Republic, Slovakia, Slovenia) have significant areas of mountains, as do Bulgaria and Romania, which joined the EU in 2007. In this context, the European Commission's DirectorateGeneral for Regional Policy commissioned a report on the mountains of the 25 countries which were currently, or soon to be, EU Member States, and also Norway and Switzerland. Two objectives were to develop a common delineation of the mountain areas of these countries, and to conduct an indepth analysis of their environmental and socioeconomic characteristics, in order to improve the evidence base on which to base future analyses and policies. To achieve the first objective, the report (Nordregio 2004) adapted the methodology of Kapos et al. (2000) to take into consideration the reality that mountains extend down to sea level in many parts of Europe, so that land below 300 masl had to be considered. This necessitated testing 16 combinations of altitude and LER to achieve a set of criteria that were acceptable to representatives of the European Commission and European mountain organisations, as well as national experts. To establish the LER for land below 300 masl, the standard deviation of the eight cardinal points surrounding each pixel of the DEM was calculated; if this was $>50 \mathrm{~m}$, the pixel was defined as 'mountain'. A final step was to approximate the resulting mountain area to municipal boundaries, given the aim of the study to compile data at the level of municipalities. For a municipality to be considered as mountainous, at least 50 percent of its $1 \mathrm{~km}^{2}$ pixels had to conform to the agreed criteria. This process meant that some land identified as 'mountain' fell outside the mountainous municipalities, and equally that these included some land that was not 'mountain'. For the study area as a whole, the respective proportions were 2.5 and 3.4 percent. Overall, mountainous municipalities covered 41 percent of the study area (1.9 million $\mathrm{km}^{2}$ ).

In 2007, the EU Member States signed the Lisbon Treaty, now integrated into the Consolidated Treaty of the Functioning of the EU (EU 2012). Its Article 174 refers to mountain regions as among those "which suffer from severe and permanent natural or demographic handicaps", further emphasizing their relevance for cohesion policy. Equally, other studies have emphasized their high levels of biodiversity (e.g., Nagy et al. 2003). Thus, two subsequent studies have considered the mountains of Europe using methodologies similar to those used by Nordregio (2004). The first was undertaken by the European Environment Agency (EEA 2010), with two adjustments to create more continuous areas: isolated mountainous areas $<10 \mathrm{~km}^{2}$ were not considered; and non-mountainous areas $<10 \mathrm{~km}^{2}$ within mountain massifs were included. The study covered all European countries, including Iceland, Ukraine, Turkey and the countries of southeast Europe that were not considered by Nordregio 
(2004). The study found that 36 percent of the area of these 41 countries was 'mountain' (Figure 1); this statistic refers to the total area according to the criteria, as the stage of allocation to municipalities was not included. The second was a study undertaken for the European Observation Network for Territorial Development and Cohesion (ESPON) 2013 Programme (ESPON and University of Geneva 2012). This covered the same countries, apart from Albania, Bosnia-Herzegovina, Macedonia, Montenegro, and Serbia, and used the same methodology as the previous study, and then identified mountain municipalities as those which were $>50$ percent 'mountain'. Continuous mountain areas of $<100 \mathrm{~km}^{2}$ were then designated as exclaves which were excluded from the

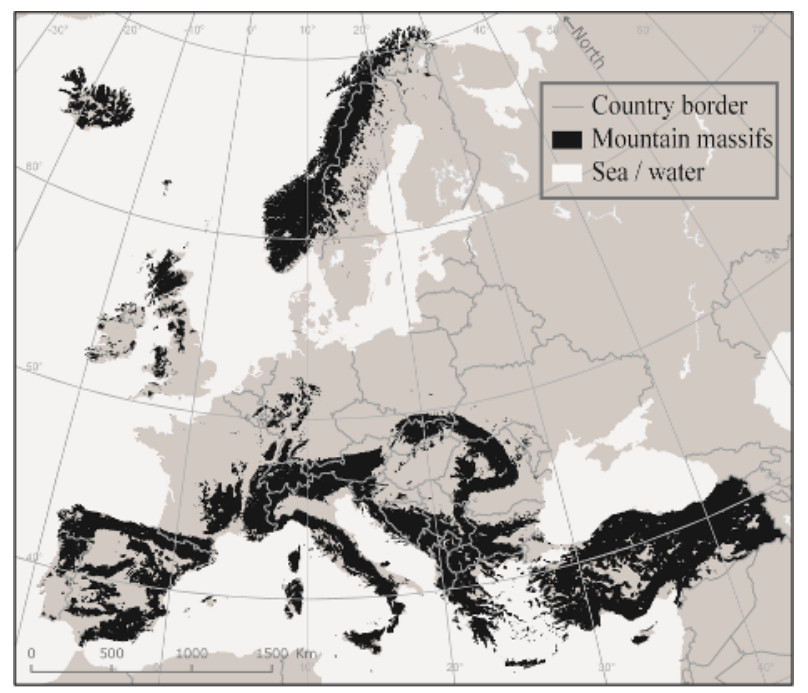

Figure 1 Mountains of Europe (EEA 2010). Reproduced with permission from the European Environment Agency. mountain delineation except on islands $<1000 \mathrm{~km}^{2}$ as, in such cases, small mountain areas were considered to constitute a greater potential constraint for social and economic activities because the total available land is limited. Similarly, non-mountainous municipality areas $<200 \mathrm{~km}^{2}$ surrounded by mountain areas were identified as enclaves and included in the mountain delineation. The study identified 29 percent of the area of the municipalities of the study area as 'mountain'. Apart from the fact that the allocation of mountain area to municipalities decreased the proportion, a further key reason for the lower value is that the five countries that were not considered are all highly mountainous (from 53 to 90 percent according to EEA 2010).

The topics considered by these three studies (Table 1) have been influenced by two factors: the commissioning institution and the availability of data. The first and third studies were commissioned by institutions with a primary interest in cohesion policy, while the main focus of the EEA is on environmental information. The first two studies also considered a number of topics through analysis at other spatial scales and/or through case studies, mainly because of the lack of consistent data across their respective study areas; and the third study includes some cross-analyses. Yet, although the results of all three studies have been used in various documents relating to the challenges and opportunities of mountain areas (e.g., European Commission 2005; Gloersen et al. 2016; ESPON 2017), none have been used as a basis for policy-making. This is because, while

Table 1 Comparison of topics mapped in three Europe-wide studies

\begin{tabular}{|c|c|c|c|}
\hline & Nordregio (2004) & EEA (2010) & ESPON (2012) \\
\hline Total population & $\mathrm{X}$ & $\mathrm{X}$ & $\mathrm{X}$ \\
\hline Population density & $\mathrm{X}$ & $\mathrm{X}$ & \\
\hline Age structure & $\mathrm{X}$ & & $\mathrm{X}$ \\
\hline Population trends & Number & Density & \\
\hline Employment & By sector & & By NACE* category \\
\hline Accessibility & Time-cost by car & Time-cost by road and railway & \\
\hline Access to urban areas & & & $\begin{array}{l}\text { Time-distance within } \\
45 \text { minutes }\end{array}$ \\
\hline Access to airports & $\begin{array}{l}\text { Time-cost by car } \times \\
\text { number of flights }\end{array}$ & & $\begin{array}{l}\text { Time-distance within } \\
45 \text { minutes }\end{array}$ \\
\hline Access to universities and hospitals & $\mathrm{X}$ & & \\
\hline Land covers/uses & $\mathrm{X}$ & $\mathrm{X}$ & \\
\hline Land cover changes & & $\mathrm{X}$ & \\
\hline Area classified under LFA Regulation & & $\mathrm{X}$ & \\
\hline High Nature Value farmland & & $\mathrm{X}$ & \\
\hline Protected areas & & $\mathrm{X}$ & \\
\hline
\end{tabular}


individual states implement policies at the scale of municipalities, cohesion policy and other EU policies are designed, implemented and evaluated at the regional level, i.e., 'NUTS 3' or even 'NUTS 2' regions (NUTS refers to Nomenclature des unités territoriales statistiques or the Nomenclature of Territorial Units for Statistics: Eurostat 2018b). Consequently, maps of the mountain areas of the EU have also been prepared for these much larger regions. Monfort (2009) classified NUTS 3 regions as mountainous if $>50$ percent of their population lived in the area defined as 'mountain' by Nordregio (2004); Dijkstra and Poelman (2011) used the same criteria, and also included regions where $>50$ percent of the area was defined as 'mountain' by Nordregio (2004). As noted by Gloersen (2012), such approaches lead to two types of problems: populations in NUTS 3 regions which have never been regarded as mountainous are included; and regions with very large uninhabited mountain areas are excluded.

In addition to these maps which focus specifically on mountain areas, two other types of maps at the European scale include such areas as specific categories. The first is the map of biogeographic regions in Europe (EEA 2018), produced in order to report on the application of the EU Habitats Directive and the EMERALD Network set up under the Convention on the Conservation of European Wildlife and Natural Habitats (Bern Convention). One of the 11 biogeographic regions is the Alpine biogeographic region, which overlaps to a significant extent with the Alps, Carpathians, and Scandes and the higher parts of the Apennines, Pyrenees and mountains of southeast Europe. For this and other regions, EU Member States report on numbers and trends in species, habitats, and Sites of Community Interest, and regular meetings of experts review these data and set priorities for future action (e.g., McIntosh and Van Uden 2017). The second map is the Environmental Stratification of Europe (ENS), developed for ecologists to use for stratified random sampling of ecological resources, selecting sites for representative studies, modelling exercises, scenario development and reporting (Metzger et al. 2005: 550). The ENS is based on statistical clustering of 20 environmental variables, including elevation and slope; most of the others are climatic. It includes three Environmental Zones that broadly correspond with mountains: Alpine North, Alpine South, and Mediterranean Mountains (Figure 2). Considerable parts of the latter two zones, particularly at lower elevations, cover territory that is not included in EEA (2018). The ENS has been used to describe broad European environmental patterns (e.g., Di Filippo et al. 2007; Holland et al. 2009), to provide units for summary reporting (e.g., Thuiller et al. 2005; Smit et al. 2008), and to develop more detailed typologies designed for use by policymakers and other stakeholders (e.g., Hazeu et al. 2011; van Eupen et al. 2012). The European Commission has used the Environmental Zones as the basis for assessing High Nature Value farmland (Paracchini et al. 2008), to identify potential areas for cultivation of bio-energy crops (EEA 2007), and to support the development of a European ecosystem map (BISE 2015).

In summary, there are many delineations and maps of Europe's mountain areas, prepared in relation to three main policy fields: agriculture, biodiversity conservation and cohesion policy. The fundamental criteria on which these maps are based are similar to those used at the global level. However, the resulting maps differ considerably, particularly when they are used to identify mountain areas not only according to topographic criteria, but also with regard to the co-occurrence of these criteria and administratively-defined entities such as municipalities and NUTS 3 and other regions.

\section{Norwegian Experiences}

As noted, many European states have produced national delineations and maps of their mountain area for the application of both national and EU legislation and policies. This section focuses specifically on the case of Norway. According to the criteria of Kapos et al. (2000), mountains cover only 59 percent of the country (Debarbieux et al. 2000). However, this is one of the European countries where mountains extend down to sea level, as considered when the methodology was revised by Nordregio (2004), which determined that 93 percent of the country's area was in mountain municipalities. Using only topographic criteria, EEA (2010) found that 78 percent of the country was 'mountain'; when these 


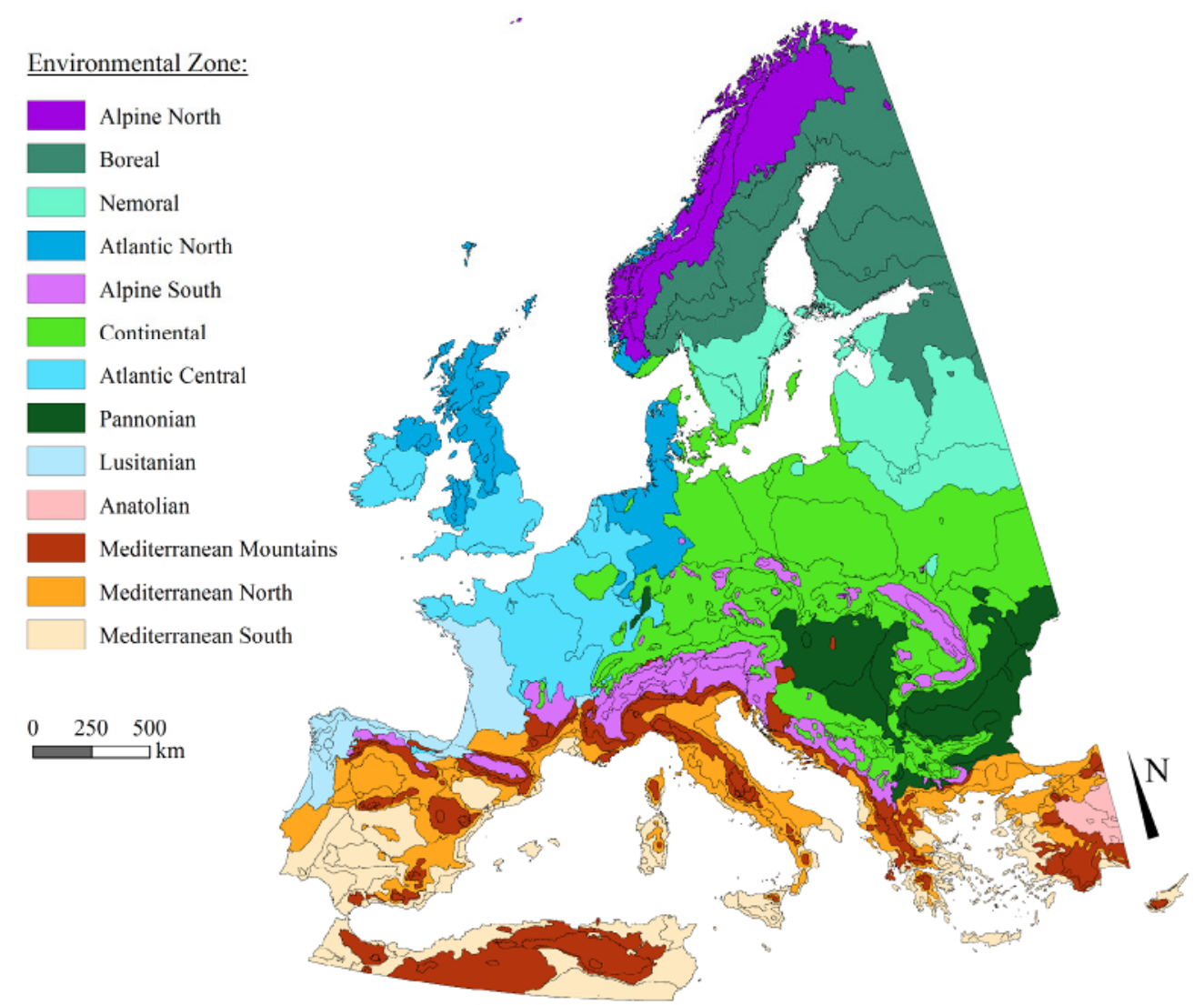

Figure 2 Environmental stratification of Europe (Metzger et al. 2005).

criteria were applied to municipalities by ESPON and University of Geneva (2012), the respective proportion was 82 percent. The section presents and discusses delineations of mountains developed within Norway, and the respective contexts.

\subsection{Landscape regions}

In the late 1980 s, the Norwegian Forestry and Landscape Institute (Norsk institutt for jord- og skogkartlegging - NIJOS) developed a national landscape reference system (Puschmann 2005), using a national adaptation of the Visual Management System developed by the US Forest Service (1974). The reference system, developed through extensive fieldwork, considered six landscape components: major landform, minor terrain form, water and watercourses, vegetation, agricultural land and built-up areas/technical installations. Elevation is not a parameter as such in the reference system, rather it is a derived feature in the landscape. The result was a division of the country into 45 landscape regions, of which nine were labelled as "mountain" (Figure 3); they cover 51.4 percent of Norway's land area.

The idea of this reference system was to highlight the different main types of landscapes and visualise "their distinctive qualities more clearly" by providing "systematic based knowledge about landscape structure, resources, characteristics and resiliency" (Puschmann 2005: 5, our translation). The goal was to "give broadspectrum information to be used as reference in administration, upkeep and priorities related to various area- and development plans" (Puschmann 2005: 9, our translation). While the reference system is "used a lot, both in national analysis and in consequence analysis" (Krøgli et al. 2015: 329, our translation), it appears to have been too detailed and too tailored to the agricultural and nature management functions to have a wider impact on rural and regional development policies. For instance, the official guide for methods of landscape analysis in municipal planning processes published by the Directorate for Nature Management (Direktoratet for Naturforvaltning 


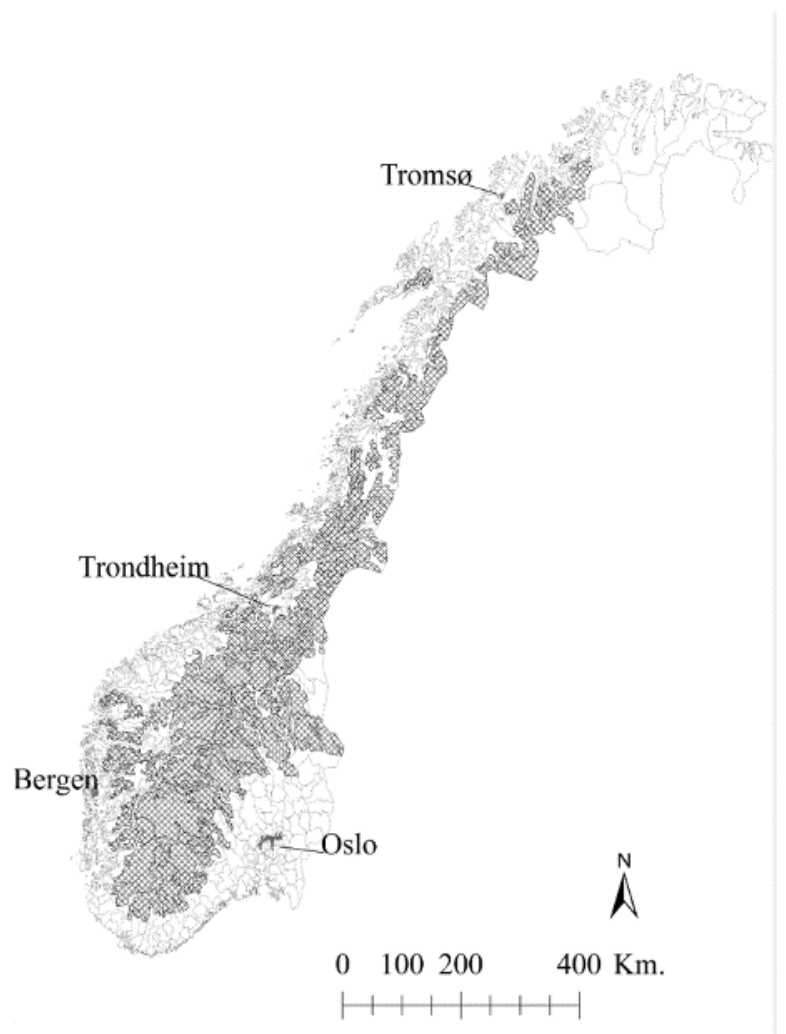

Figure 3 Regions containing the label 'mountain' in the NIJOS national landscape reference system (Puschmann 2005).

2011) does not refer to the reference system. However, it is interesting because it delimits mountainous geographical units without the use of elevation as a quantitative parameter. As such, it avoids the question raised initially in this paper, on the existence of mountains.

\subsection{The evolving policy context for defining mountain areas}

The Ministry of Regional and Municipality Affairs (now The Ministry of Local Government and Modernisation), which is responsible for rural and regional policy, national mapping and geodata policy, participated in the analysis of Nordregio (2004). However, while the national landscape reference system discussed above may have been too detailed, the delineation by Nordregio (2004) of almost all the country (93 percent) as 'mountain' meant that it was of little use for domestic regional policy making, in which it is necessary to be able to distinguish and characterize 'this from that'. Consequently, in 2009, the ministry commissioned a project aimed at adapting the Nordregio (2004) analysis to domestic policy applications.

At the time and from an external perspective, Norway had no national delimitation of its mountain area, and no national mountain policy: as for other largely mountainous countries, such as Greece and Slovenia, "mountain policy [was] synonymous with general development policy" (Nordregio 2004: 148). The initiative by the ministry, both by participating in the Nordregio study and by commissioning an adaptation for domestic purposes, represented initial attempts from a governmental perspective to address the issue of defining the national mountain area within the context of rural and regional development. The underlying problematique was of policy relevance: Is there a rationale for distinguishing a mountain parameter within rural and regional general development policy which was, at the time, placeblind or geographic specificity-blind? Would the parameter 'mountain' enclose a group of municipalities that share a development problematique?

A quest for a domestic mountain policy had been developing for a while, primarily through bottom-up initiatives, as central government seemed to pay little attention to mountains as an explanatory variable of relevance to national or regional policy. As noted at the beginning of this paper, political processes for mountain policies had been catalysed by actors at the global scale since the early 1990s, and mountains were accorded a chapter in 'Agenda 21' (A21). Since the Norwegian government had been an international promoter of sustainable development, domestic expectations for the implementation of A21 in Norway were high (Coenen et al. 2003), particularly with regard to Local Agenda 21 (LA21), which aimed to bring sustainable development actions to the level of the "lives of ordinary people" (Voisey et al. 1996: 33). However, Norway was slow to begin implementing LA21 (Eckerberg et al. 1999). Until 1997, the Ministry of the Environment was reluctant to admit that LA21, which was to be applied at the municipality level, represented anything beyond what was involved in the national environmental programme, 'Environmental Policy in the Municipality', which ran from 1987 to 1991 (Lafferty et al. 2006). Yet, while several of the 90 municipalities involved were mountainous, the 
programme had no specific focus on the mountain area, and documents guiding LA21 processes in Norway, such as the ministerial guide from 1998 for the preparation of municipal area plans (Miljøverndepartementet 1998) make no reference to the mountain chapter of A21. While this chapter could have presented a welcome opportunity to Norway and its mountain communities, there was a peculiar form of blindness about the relevance of the mountain parameter in Norwegian rural development policy.

However, political pressure was building from below. Notably, between 2002 and 2004, several county councils, municipalities, and regional cooperation structures between municipalities, all in inland mountain regions, established, with active help from the Ministry of Municipality and Modernisation, the political association Fjellregionsamarbeidet (The Mountain Region Cooperation), renamed Fjellnettverket (The Mountain Network) in 2016. This had and has a specific aim to push for a mountain policy, to secure "living and vigorous mountain villages" (Fjellnettverket 2018, our translation) - but this was not based on a nationwide definition or characterization of the country's mountain area and mountain societies.

A further initiative addressing mountain issues, still without a definition of mountain areas, emerged in the additional budget proposition to the Parliament from the Ministry of Finance in 2003. The proposition, a supplement to the National Budget, included a section entitled "Fjellområdene - bruk, vern og verdiskaping", "Mountain areas - use, protection and value creation" (Ministry of Finance 2003: 140-153, our translation), more often referred to as "Fjellteksten" or "The Mountain Text". This briefly touches upon the issue of mountain definition:

The Government assumes that "mountain areas" in this context include areas where values and characteristics in the mountains are important for industrial development and localization of buildings. The Government believes that such a functional demarcation of "mountain areas" is the most appropriate to answer the Storting's request. (Ministry of Finance 2003: 140, our translation)

However, this statement was not complemented by a map or a list of mountain areas. Its core message was that protected areas - i.e., national parks in mountain areas - could be used in branding, and that "increased sustainable tourism activities not conflicting with the purpose of protection of national parks" (Ministry of Finance 2003: 146, our translation) should be promoted. This text was the first very rudimentary formulation of a national mountain policy with a rather vague definition of mountain area. While it had negligible practical effects (Skjeggedal et al. 2013), it was an indication of how the discourse on mountains and development policy approaches cannot be sufficiently understood solely by referring to the general rural and regional development policy.

In a predominantly mountainous country such as Norway, most sectoral policies unfold in mountain areas. As discussed above, some sectors had conceptualized mountainous landscape regions in targeted policy instruments; others were de facto mountain policy by operating almost exclusively in mountains. Policies for four sectors can illustrate this: hydro power; national parks; agriculture; and tourism and second homes. Hydro power policy almost exclusively and de facto refers to and unfolds in mountain areas, but operates independent of a mountain definition (Arnesen 1999). National park policy has, until quite recently, exclusively been implemented in mountain areas, but does not rest on a definition of mountains as such (Arnesen 1998). Agricultural policy has distinguished lowland from mainly mountainous areas. Through various subsidy instruments, the government has devised a division of labour, effectively guiding mountainous regions towards dairy and meat production and extensive grazing. While such policies have not been founded on, or provided a foundation for, a general delimitation of mountain areas, agriculture has long been a starting point and a prime concern in studies of mountain communities. Hansen (1976) was a pioneer in researching various classifications of mountain regions and mountain communities, the growing economic importance of tourism and recreational use of mountain areas, and the resulting opportunities for agriculture and local food production. However, lack of data and of the type of GIS tools now available meant that his work was not followed up at the time.

The impact of tourism in mountain areas had been focussed on even earlier, when Holt-Jensen 
(1963) asked 'what is a mountain community?' His concern was the profound upheaval in mountain communities due to ongoing technological and economic development. His argument was that agriculture had to switch from subsistence-based to de facto contract production and sales operations, as the steady expansion and centralization of other industries pulled labour out of agriculture and mountain communities. In 1962, the government established a 'mountain planning team' to draft regulation models for a few mountain areas "in order to illustrate to what extent it is possible to implement good zoning plans in mountains given the existing legal framework and the administrative practice we now have" (Sømme et al. 1965: 5, our translation). The concern to be addressed was the growing leisure and vacation activity in mountains, with the development of condominiums and tourism facilities, increasing the need for protection and the regulation of development. However, this work was not based on, and did not result in, a general definition of the mountain area, and the discourse revolved around the transformation of agriculture in the mountains with negative repercussions for mountain communities, in parallel with the emergence of modern tourism and second home developments (Arnesen and Ericsson 2013). The entailing policy responses focussed on identity and regulation, and partly came together in devising the division of labour and production in agriculture between lowland and higher-elevation agricultural land mentioned above, speeding up the establishment of national parks, and giving the municipalities a reinforced competence in the Planning and Building Act, which has undergone many revisions to empower local-level processes (Skjeggedal et al. 2016; Overvåg et al. 2016).

\subsection{An elevation approach to mountains}

As noted above, in 2009 the Ministry of Regional and Municipality Affairs commissioned a project to adapt the approach used by Nordregio (2004) to fit the South Norwegian context: i.e. Norway from the county of Nord-Trøndelag and southward. Why the commissioned project was limited to mountains in Southern Norway, and did not address the entire country, is unclear. In later analysis, the topographical analysis was extended to include the rest of the country, as discussed below. The project had three objectives, with a clear policy intent:

(1) to identify, delimit and characterize mountain areas and mountain municipalities;

(2) to analyse the characteristics of mountain municipalities, compatible with existing national datasets;

(3) to shed light on current challenges, difficulties and opportunities for mountain municipalities.

The main adaptation was to "slice" the mountain area, as defined by Nordregio (2004), into two elevation levels: high mountains and coastal mountains. Norway has a long rugged coastline: $2532 \mathrm{~km}$ by the baseline, and 28,953 $\mathrm{km}$ if fjords and bays are included. The adaptation assumed that, although coastal mountain areas have mountainous topography, in a policy dimension they differ significantly from high mountain and inland areas. 80 percent of Norway's population live within 10 kilometres of the coast; in northern Norway, as much as 90 percent within 4 kilometres (Statistics Norway 2013). Access to infrastructure such as hospitals, airports, ports, railroads, universities, and roads is generally much more developed along the coast than inland. Access to the sea offers a resource in logistic and economic terms and, since the 1980 s, many coastal societies have had access to growth impulses, not least from offshore industries and fish farming. So, by lifting the 'floor' of the domestic delimitation of mountain areas sufficiently, it would better capture the regions that, in a rural development perspective, are more challenged.

The threshold values chosen for the project define all land at least 700 masl, and 600 masl from Nord-Trøndelag northwards, as 'mountain area' (Arnesen et al. 2010; Skjeggedal and Overvåg 2015). Isolated mountain areas less than $5 \mathrm{~km}^{2}$ are excluded, and "pockets" of land lower than $700 / 600$ masl surrounded by a mountain area are included, following the same procedure as Nordregio (2004). The rationale for choosing the 700/600 masl threshold was twofold:

(1) As an approximation, most productive forestry occurs at up to about 700 masl in southern Norway, and to lower elevations northwards. However, there is no coherent definition of 
productive forest boundary, and it varies locally (Larsson 2004). Slightly more than 10 percent of the productive forestry area occurs above the threshold, up to 800+ masl (Norsk institutt for bioøkonomi 2018).

(2) Possibly more controversially, Arnesen et al. (2010) also refer to a cultural component for the 700 / 600 masl threshold. This relates to the distinction, embodied in daily language, between being 'on a mountain' and 'in the mountains'. While one cannot devise a definitive ontological delineation from this distinction, it does give relevant guidance: when leaving the coast, what is elevation about when you are said to be in the mountains? The study team did a qualitative survey of mountain guide books, mountain tourism and travel information (web pages, books) - in short, daily life language sources showing how the language of being 'in the mountains' is used and where it applies - and concluded that a 700 / 600 masl threshold would enclose relevant mountain areas when referring to being 'in the mountains'.

The analysis (Arnesen et al. 2010; Skjeggedal \& Overvåg 2015) concluded that the mountain area covered 30 percent of Norway's land area (42 percent in Southern Norway and 16.5 percent in Northern Norway) (Figure 4). Using the criterion that mountain municipalities have at least 50 percent of their territory within the mountain area, 89 mountain municipalities were identified: 20.7 percent of all Norwegian municipalities. In terms of population potential, mountain municipalities as a group lag substantially behind the national average, both with regard to developments in recent decades and at present. These municipalities have had a negative demographic development since 1990, in contrast to the average of municipalities elsewhere in Norway. While levels of registered employment and unemployment within the mountain area vary, these levels are generally low. The industrial structure in mountain municipalities, including the share of employees working in the public sector, is close to the national average. Finally, these municipalities suffer from pronounced difficult accessibility.

Today, mountain municipalities are among those that are already targeted by the most comprehensive rural development policy instruments. Is this the end of the story; are

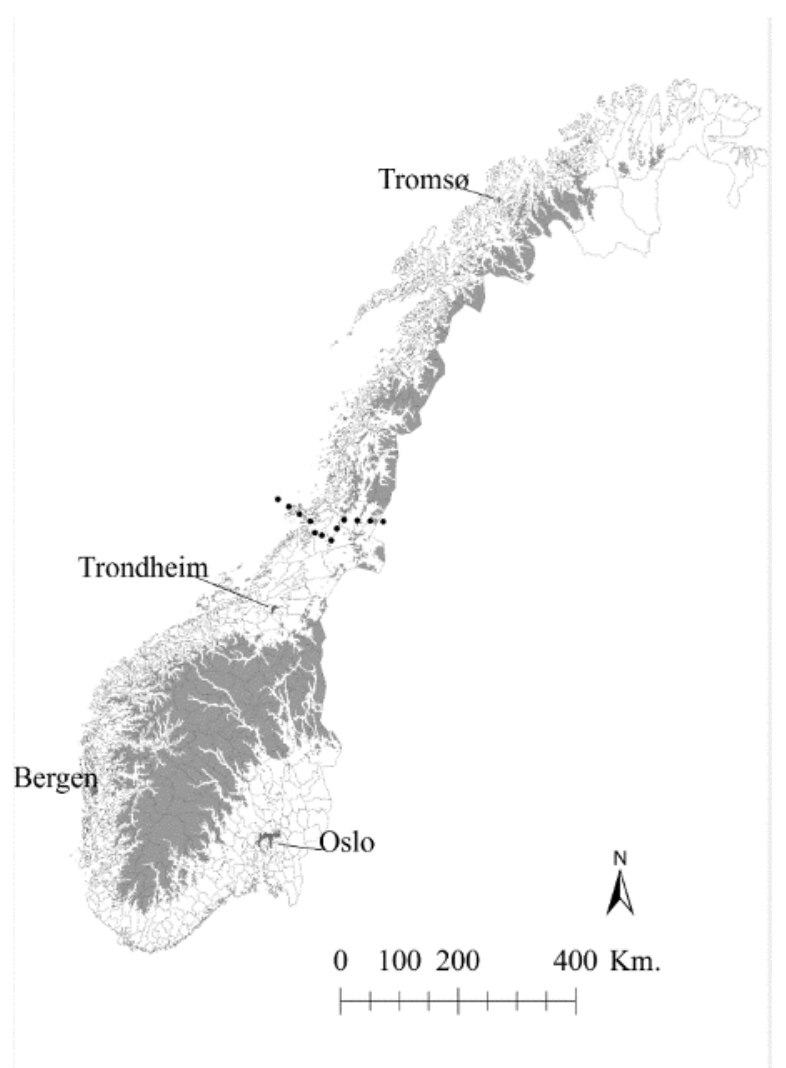

Figure 4 Mountain area of Norway (Arnesen et al. 2010; Skjeggedal and Overvåg 2015). The dotted line shows the border between Southern and Northern Norway used in the study.

mountain municipalities already included in geographic specificity "blind" rural development policies to the extent that there is no real policy function for a mountain delineation? With some exceptions, this is the starting point for the discourse on the need for a targeted mountain policy within rural development policy in Norway. The exceptions are:

- Fjellnettverket (The Mountain Network) mentioned above, has adapted the delineation shown in Figure 4 as their working definition for mountain area and mountain municipalities, and also for the development challenges and situation for these municipalities.

- The Ministry of Local Government and Modernisation has established a 5-year programme aimed at wealth creation and economic development in mountainous areas. The annual budget for the programme is just above $€ 1$ million. Eligible applicants to the programme must be in a mountain municipality, confined to Southern Norway, as defined in Arnesen et al. (2010). 
Thus, the definitions of mountain area and mountain municipality developed by Arnesen et al. (2010) have de facto been adopted in some cases, but as 'rough consensus and running code' rather than official definitions. A final point is that these definitions are specifically intended to address the domestic situation. From a multilateral perspective, Norway may well be understood as mainly a mountainous country, even to the level of 93 percent of its area as being mountainous (Nordregio 2004). In such a context, this goes to show that development status and dynamics may vary considerably within mountain areas, and that understanding of the spatial and functional relations between mountains and other geographical specificities - such as being a coastal area - is required to analyse the policy implications of being in a mountain area.

\section{Discussion and Conclusions}

The primary focus of this paper has been on Europe and its countries, as this is where the majority of experiences of mapping mountain areas have emerged. However, atlases of the mountain areas of other continents (Africa: UNEP 2014; Hindu Kush-Himalaya: Zurick and Pacheco 2006) have also been produced, as have atlases and databases of transnational mountain ranges in Europe (e.g., Alps: Tappeiner et al. 2008; Carpathians: Ruffini and Ptacek 2009; Pyrenees: SIG-Pyrenees 2018). With the exception of the first of these, which defined mountains as land above 1500 masl, the areas mapped have been defined using administrative criteria, respectively: the area considered by the International Centre for Integrated Mountain Development (ICIMOD 2018); and the perimeters of the territory concerning the Alpine and Carpathian Conventions and the Working Community for the Pyrenees. For the Alps, the relatively restricted territory subject to the Alpine Convention is only one of three perceptions of the extent of the Alps; other focus more on the functional region (e.g., Balsiger 2016).

Overall, these experiences show that two types of approaches have been taken to mapping mountains at global, regional, and national scales. The first has considered mountains per se, based on elevation and/or topography (e.g., Kapos et al.
2000 and subsequent studies using this classification; Körner et al. 2017; Nordregio 2004; EEA 2010; ESPON and University of Geneva 2012; Arnesen et al. 2010). Following the initial definition of mountain area, this has then been characterised with regard to a number of variables. The resulting statistics and analyses have then been used for the purposes of research or advocacy. Examples include research being done by the Global Mountain Biodiversity Assessment network and the advocacy of the global Mountain Partnership, Euromontana and the Norwegian Mountain Network, all to give greater attention to the challenges faced by, and opportunities for, mountain areas and their inhabitants. In one case, in Norway, the delineation has been used by policymakers: to define the 'mountain municipalities' which are eligible for funding. It should be noted that other countries have passed legislation that defines their national mountain areas, municipalities, or settlements (i.e., generally those above a specific altitude, but also sometimes considering other factors) for such targeted funding. These countries are mainly in Europe (Bulgaria, France, Georgia, Italy, Romania, Switzerland, Ukraine); a few are in other parts of the world (Algeria, Kyrgyzstan) (Castelein et al. 2006).

The second approach has been to consider mountains as one of a number of categories that, together, characterise either the entire landmass of the world, or parts of it, in terms of landforms, both globally (Sayre et al. 2014; Karagulle et al. 2017) and, for example, in China (e.g., Cheng et al. 2011, 2017; Tang 2017) or biogeographic, environmental or landscape zones (e.g., EEA 2018; Metzger et al. 2005; Puschmann 2005). Some of these delineations have been used as the basis for further research. While their use for policy-making has been proposed, this goal has not been realised, though the map of biogeographic regions of Europe (EEA 2018) is used for reporting on the application of policy instruments.

At the global scale, the 'Global Mountain Explorer' website allows the comparison of three global delineations, derived from these two approaches. This website is an activity of the Geo Global Network for Observation and Information in Mountain Environments (GEO-GNOME), which aims to "delineat[e] accurately mountain regions 
using best available data" and use the resulting data and information to respond to future policy needs (Group on Earth Observations 2018). Yet, while 'objective' scientific criteria (e.g., topographic, biogeographic or landscape classifications) can be regarded as 'naturalistic' conceptions for mapping mountains, 'constructionist' approaches defined by more subjective characteristics or policy imperatives can also be relevant (Debarbieux and Rudaz 2015). As noted by Peattie (1936), the appropriate minimum altitude for the top of a 'mountain' or mountain range may well depend on its role in the popular imagination, its individuality, or its symbolic role for local people; one example is the distribution of place names in South Africa including the word 'mountain' (Browne et al. 2004). Sometimes, such approaches can be used together, as exemplified by the use of Norwegians' cultural associations with mountains as a preliminary step in defining a minimum elevation threshold (Arnesen et al. 2010). To conclude, all attempts to map mountain areas will continue to be inextricably bound with the objectives of

\section{References}

Arnesen T (1998) Landscapes lost. Landscape Research 23(1): 39-50.

Arnesen T (1999) The hydropower policy evolution, planning and decision making in Norway in $20^{\text {th }}$ century with a reference to the G\&L-basin. In: Norwegian Institute for Nature Research and Eastern Norway Research Institute, The Glomma and Laagen Basin, Norway: A case study prepared as an input to the World Commission on Dams, Cape Town. pp 81-113.

Arnesen T, Ericsson B (2013) Policy responses to the evolution in leisure housing: From the plain cabin to the high standard second home. The Norwegian case. In: Roca IZ (ed.), Second Home Tourism in Europe: Lifestyle Issues and Policy Responses. Ashgate, Farnham. pp 285-308.

Arnesen T, Overvăg K, Gløersen E, Schurman C, Riise Ø (2010) Fjellområder og fjellkommuner i Sør-Norge. Definisjon, avgrensing og karakterisering [Mountain areas and mountain communes in South Norway. Definition, delineation and characterisation]. Report 08/2010 Lillehammer: Østlands forskning.

Ariza C, Maselli D, Kohler T (2013) Mountains: Our Life, Our Future. Progress and Perspectives on Sustainable Mountain Development from Rio 1992 to Rio 2012 and Beyond. Bern: Swiss Agency for Development and Cooperation and Centre for Development and Environment.

Balsiger J (2016) The European Union Strategy for the Alpine Region. In: Gãnzle S, Kern K (eds.), A Macro-regional Europe in the Making: Theoretical Approaches and Empirical Evidence. Palgrave Macmillan, New York. pp 189-213.

BISE (2015) Map of European Ecosystems. (http://biodiversity.europa.eu/maes/mapping-

ecosystems/map-of-european-ecosystem-types, accessed on 2018-02-19).

Blyth S, Groombridge B, Lysenko I, et al. (2002) Mountain Watch: Environmental Change and Sustainable Development in Mountains. Cambridge: UNEP World Conservation Monitoring Centre.

Browne T, Fox R, Funnell D (2004) The "invisible" mountains: thosecommissioning and/or undertaking the work, whether driven by scientific, political or policy imperatives. There is no unitary definition of 'mountain' at the scale of the Earth as a whole, or for Europe, and this is likely to continue to be so.

\section{Acknowledgements}

The Norwegian case study was financed under a contract with Ministry of Local Government and Modernisation in Norway.

\section{Open Access}

This article is distributed under the terms of the Creative Commons Attribution 4.0 International License (http://creativecommons. org/licenses/by/4.o/), which permits unrestricted use, distribution, and reproduction in any medium, provided you give appropriate credit to the original author(s) and the source, provide a link to the Creative Commons license, and indicate if changes were made.

Using GIS to examine the extent of mountain terrain in South Africa. Mountain Research and Development 24: 28-34.

Bunazzo M (2016) The history and evolution of cohesion policy. In: Piattoni S, Polverari L (eds.), Handbook on Cohesion Policy in the EU. Edward Elgar, Cheltenham. pp 17-35.

Byers AC, Price LW, Price MF (2013) An introduction to mountains. In: Mountain Geography: Physical and Human Dimensions. Berkeley: University of California Press. pp 1-10.

Castelein A, Dinh TTV, Mekouar MA, Villeneuve A (2006)

Mountains and the Law: Emerging Trends. FAO Legislative Study, Rev. 1. Rome: Food and Agriculture Organization of the United Nations.

Cheng WM, Zhou CH, Chai HX, et al. (2011) Research and compilation of the geomorphologic atlas of the People's Republic of China (1:1,000,00o). Journal of Geographical Sciences 21(1): 89-100. https://doi.org/10.1007/s11442-011-0831-Z Cheng WM, Liu Q, Zhao S, et al. (2017) Research and perspectives on geomorphology in China: Four decades in retrospect. Journal of Geographical Sciences 27(11): 12831310. https://doi.org/10.1007/s11442-017-1436-y

Coenen F, Norland I, Bjornaes T (2003) Local Agenda 21 in the Nordic Countries -national strategies and local status (Report No. 1/03). Oslo: ProSus - Senter for utvikling og miljø University of Oslo.

Debarbieux B, Balsiger B, Djordjevic D, et al. (2014) Scientific collectives in region-building processes. Environmental Science and Policy.

https://doi.org/10.1016/j.envsci.2014.06.005

Debarbieux B, Delannoy JJ, Dobremez JF (2000) Les pays du monde et leurs montagnes [The countries of the world and their mountains]. Grenoble: Editions Revue de Géographie Alpine.

Debarbieux B, Price MF (2008) Representing mountains: From local and national to global common good. Geopolitics 13: 148-168.

Debarbieux B, Price MF, Balsiger J (2013) The institutionalization of mountain regions in Europe. Regional Studies. https://doi.org/10/1080/00343404.2013.812784 
Debarbieux B, Rudaz G (2015) The Mountain: A Political History from the Enlightenment to the Present. Chicago: University of Chicago Press.

Di Filippo A, Biondi F, Cufar K, et al. (2007) Bioclimatology of beech (Fagus sylvatica L.) in the Eastern Alps: spatial and altitudinal climatic signals identified through a tree-ring network. Journal of Biogeography 34: 1873-1892.

Dijkstra L, Poelman H (2011) Regional Typologies: A Compilation. Regional Focus 01/2011. Brussels: DirectorateGeneral for Regional Policy, European Commission.

Direktoratet for naturforvaltning (2011) Veileder. Metode for landskapsanalyse i kommuneplan [Guide. Method of landscape analysis in the municipal plan]. Trondheim: Direktoratet for naturforvaltning [Norwegian Environment Agency].

Eckerberg K, Coenen F, Lafferty WM (1999) The Status of LA21 in Europe: a comparative overview. In: Lafferty WM (ed.), Implementing LA21 in Europe: New Initiatives for Sustainable Communities. ProSus, Oslo. pp 241-261.

ESPON (2017) Revealing territorial potentials and shaping new policies in specific types of territories in Europe: islands, mountains, sparsely populated and coastal regions. ESPON Working Paper. Luxembourg: ESPON EGTC.

ESPON and University of Geneva (2012) Geographical Specificities and Development Potentials in Europe: Final Scientific Report.

(https://www.espon.eu/sites/default/files/attachments/GE OSPECS_Final_scientific_report_v2_-_revised_version.pdf, accessed on 2018-02-19)

European Commission (2005) Mountainous Areas of the European Union. Luxembourg: Office for Official Publications of the European Communities.

European Environment Agency (EEA) (2007) Estimating the Environmentally Compatible Bioenergy Potential from Agriculture. EEA Technical Report 12. Copenhagen: European Environment Agency.

European Environment Agency (EEA) (2010) Europe's Ecological Backbone: Recognising the true value of our mountains. Copenhagen: European Environment Agency.

European Environment Agency (EEA) (2018) Biogeographical regions in Europe.

(https://www.eea.europa.eu/data-and-

maps/data/biogeographical-regions-europe-3, accessed on 2018-02-19)

European Union (2012) Consolidated version of the Treaty of the Functioning of the European Union 2012/C 362/49, 26 October 2012

(http://eur-lex.europa.eu/legal-

content/EN/TXT/?uri=celex\%3A12012E\%2FTXT, accessed on 2018-02-19)

Eurostat (2018a) Glossary: Statistical classification of economic activities in the European Community (NACE). (http://ec.europa.eu/eurostat/statistics-

explained/index.php/Glossary:Statistical_classification of e conomic_activities_in_the_European_Community_(NACE), accessed on 2018-05-07)

Eurostat (2018b) NUTS - Nomenclature of Territorial Units for Statistics: Overview. (http://ec.europa.eu/eurostat/web/nuts, accessed on 2018-02-19)

Felber R (1992) Foreword by the President of the Swiss Confederation. In: Stone PB (ed.), The State of the World's Mountains. London: Zed Books. p. xvii.

Fjellnettverket (2018) Fjellnettverket [The Mountain Network]. (http://www.bfk.no/Fjellnettverket/, accessed on 2018-02-19).

Gloersen E (2012) Renewing the theory and practice of European applied research on mountain, islands and sparsely populated areas, Regional Studies. https://doi.org/10/1080/00343404.2112.665989

Gloersen E, Price MF, Borec A, et al. (2016) Research for the REGI Committee - Cohesion in Mountainous Regions of the EU. Brussels: Directorate-General for Internal Policies, European Parliament.

Group on Earth Observations (2018) Geo Global Network for Observation and Information in Mountain Environments (GEO-GNOME)

(https://www.earthobservations.org/activity.php?id=117, accessed on 2018-02-19)

Hansen JC (1976) Mountain communities in Norway. Norsk Geografisk Tidsskrift - Norwegian Journal of Geography 30(4): 211-220. https://doi.org/10.1080/00291957608552006

Hazeu GW, Metzger MJ, Mücher CA, et al. (2011) European environmental stratifications and typologies: An overview. Agriculture, Ecosystems and Environment 142: 29-39.

Holland EP, Burrow JF, Dytham C, Aegerter JN (2009) Modeling with uncertainty: introducing a probabilistic framework to predict animal population dynamics. Ecological Modeling 220: 1203-1217.

Holt-Jensen A (1963) Hva er en fjellbygd [What is a mountain settlement] ? Norsk Geografisk Tidsskrift - Norwegian Journal of Geography 19(3-4): 113-139.

https://doi.org/10.1080/00291956308551811

Huddleston B, Ataman E, de Salvo P, et al. (2003) Towards a GIS-based analysis of mountain environments and populations. Rome: Food and Agriculture Organization of the United Nations.

ICIMOD (2018) Hindu Kush Himalayan Region. (http://www.icimod.org/?q=1137, accessed on 2018-02-19)

Ives JD, Messerli B, Spiess E (1997) Mountains of the World - A global priority. In: Messerli B, Ives JD, (eds.), Mountains of the World: A global priority. Parthenon, Carnforth and New York. pp 1-15

Kapos V, Rhind DJ, Edwards M, et al. (2000) Developing a Map of the World's Mountain Forests. In: Price MF, Butt N (eds.), Forests in Sustainable Mountain Development: A Report for 2000. CAB International, Wallingford. pp 4-9.

Karagulle D, Frye C, Sayre R, et al. (2017) Modeling global Hammond landform regions from 250-m elevation data. Transactions in GIS 21: 1040-1060.

Kohler T, Hurni H, Imbach K, et al. (2001) Mountains and People: An Account of Mountain Development Programmes Supported by the Swiss Agency for Development and Cooperation (SDC). Bern: Swiss Agency for Development and Cooperation.

Kohler T, Wehrli A, Jurek M (2014) Mountains and Climate Change: A Global Concern. Bern: Swiss Agency for Development and Cooperation and Centre for Development and Environment.

Körner C, Jetz W, Paulsen J, et al. (2017) A global inventory of mountains for bio-geographical applications. Alpine Botany 127:1-15.

Körner C, Paulsen J, Spehn E (2011) A definition of mountains and their bioclimatic belts for global comparisons of biodiversity data. Alpine Botany 121: 73-78

Krøgli SO, Fjellstad W, Flo Heggem ES, et al. (2015) Landskap i ruter - et fleksibelt system for landskapsanalyser [Landscape in rectangles - A flexible system for landscape analysis]. Kart og plan 4: 328-341.

Lafferty W, Aall C, Norland I (2006) Lokal Agenda 21 i Norge: Så mye hadde vi - så mye ga vi bort - så mye har vi igjen [Local Agenda 21 in Norway: This we had - This we gave away - This is what we have left]. Oslo: Unipub forlag.

Larsson JY (2004) Skoggrensa i Norge - indikator på endringer i klima og arealbruk? [Forest limit in Norway - indicator of changes in climate and land use?] NIJOS dokument 03/2004. Ås: Norsk institutt for jord- og skogkartlegging [Norwegian Institute for Soil and Forestry].

Louis H (1975) Neugefasstes Höhendiagramm der Erde. Bayerische Akademie der Wissenschaften (MathematischeNaturwissenschaftische Klasse). pp 305-326.

McIntosh N, van Uden G (eds.) (2017) Seminar Input Document, Second Alpine Natura 2000 Seminar. Padova, Italy, 21-23 June 2017.

(http://ec.europa.eu/environment/nature/natura200o/platfo $\mathrm{rm}$ /documents/alpine seminar_second/input document 2n d\%20alp\%20seminar_2017_en.pdf, accessed on 2018-02-19)

Metzger MJ, Bunce RGH, Jongman RHG, Mücher CA, Watkins JW (2005) A climatic stratification of the environment of Europe. Global Ecology and Biogeography 14, 549-563.

Meybeck M, Green P, Vörösmarty C (2001) A new typology for mountains and other relief classes: an application to global continental water resources and population distribution. Mountain Research and Development 21: 34-45.

Miljøverndepartementet (1998) MD-1506 Kommuneplan. Veileder for utarbeiding av kommuneplanens arealdel etter bestemmelsene i plan- og bygningsloven [MD-1506 Municipal Plan. Guidelines for the preparation of the municipal land-use plans under the provisions of the Planning and Building Act] Oslo: Miljøverndepartementet [Ministry of Climate and Environment]. 
Ministry of Finance (2003) St.prp. nr. 65 2002-2003 Tilleggsbevilgninger og omprioriteringer i statsbudsjettet medregnet folketrygden 2003 [Proposition No. 65 2002-2003 Additional appropriations and re-priorities in the state budget, including the National Insurance Scheme 2003]. Oslo: Ministry of Finance.

(https://www.regjeringen.no/contentassets/85893b5b44ea4 $8929197 \mathrm{fcda2234 \textrm {be } 6 \mathrm { c } / \mathrm { no } / \mathrm { pdfs } / \mathrm { stp } 2 0 0 2 2 0 0 3 0 0 6 5 0 0 0 d d d p}$ dfs.pdf , accessed on 2018-02-19)

Monfort P (2009) Territories with Specific Geographical Features. Working Paper 02/2009. Brussels: European Commission.

Mountain Agenda (2002) Mountains of the World: Sustainable Development in Mountain Areas - The Need for Adequate Policies and Instruments. Bern: Centre for Development and Environment.

Nagy L, Grabherr G, Körner C, Thompson DBA (eds.) (2003) Alpine Biodiversity in Europe. Berlin: Springer.

Norsk institutt for bioøkonomi (NIBIO) (2018) Produktivt skogareal og høydesoner [Productive forest area and altitude zones].

(http://www.skogoglandskap.no/Artsbeskrivelser/produktivt _skogareal_og_hoydesoner, accessed on 2018-02-19)

Nordregio (2004) Mountain Areas in Europe: Analysis of Mountain Areas in EU member States, Acceding and other European Countries. Nordregio Report 2004: 1, Report to the Directorate-General for Regional Development, European Commission. Stockholm: Nordregio.

Nürk MN, Michling F, Linder HP (2018) Are the radiations of temperate lineages in tropical alpine ecosystems pre-adapted? Global Ecology and Biogeography 27(3): 334-345.

Overvåg K, Skjeggedal T, Sandström C (2016) Management of mountain areas in Norway and the persistence of localnational conflicts. Journal of Environmental Planning and Management 59(7): 1186-1204.

Oxford English Dictionary (2018) Mountain. Oxford University Press, Oxford.

(http://www.oed.com/view/Entry/122893?rskey=nSUNxR\&r esult=1\&isAdvanced=false, accessed on 2018-02-19)

Paracchini ML, Petersen JE, Hoogeveen Y, et al. (2008) High nature value farmland in Europe, an estimate of the distribution pattern on the basis of land cover and biodiversity data. JRC Scientific and Technical Report EUR 23480. Ispra, Italy.

Peattie R (1936) Mountain Geography: A critique and Field Study. New York: Greenwood.

Price MF (2015) Mountains: A Very Short Introduction. Oxford: Oxford University Press.

Price MF, Butt N (eds.) (200o) Forests in Sustainable Mountain Development: A Report for 2000. Wallingford: CAB International.

Puschmann O (2005) Nasjonalt referansesystem for landskap. Beskrivelse av Norges 45 landskapsregioner [National landscape reference system. Desecription of Norway's 45 landscape regions]. NIJOS report 10/2005. Ås: Norsk institutt for jord- og skogkartlegging.

Rodríguez-Rodríguez D, Bomhard B (2012) Mapping direct human influence on the world's mountain areas. Mountain Research and Development 32:197-202.

Rodríguez-Rodríguez D, Bomhard B, Butchart SHM, Foster MN (2011) Progress towards international targets for protected area coverage in mountains: A multi-scale assessment. Biological Conservation 144: 2978-2983.

Romeo R, Vita A, Testolin R, Hofer T (2015) Mapping the vulnerability of mountain peoples to food insecurity. Rome: Food and Agriculture Organization of the United Nations.

Rudaz G (2009) Territorial redefinition and the governance of mountain regions. Journal of Alpine Research/Revue de Géographie Alpine. https://doi.org/10.4000/rga.866
Ruffini FV, Ptacek P (2009) Atlas of the Carpathian Macroregion. Olomiuc: Palacky University.

Sayre R, Dangermond J, Frye C, et al. (2014) A new map of global ecological land units - an ecophysiographic stratification approach. Washington, DC: Association of American Geographers.

SIG-Pyrenees (2018) Atlas statistique des Pyrénées [Statistical Atlas of the Pyrenees].

(http://atlas.ctp.org/site_fr/index_fr.php?lang=fr, accessed on 2018-02-19)

Skjeggedal T, Overvåg K (eds.) (2015) Fjellbygd eller feriefjell [Mountain communities or mountains for recreation]? Bergen: Fagbokforlaget Vigmostad \& Björke AS.

Skjeggedal T, Overvăg K, Riseth JA (2016) Land-use planning in Norwegian mountain areas: local development or nature protection? European Planning Studies 24(2): 344-363.

Skjeggedal T, Overvåg K, Ringholm T and T (2013) Ti år med "fjellteksten " [Ten years with the "mountain text"]. Tidsskriftet UTMARK 2013:1.

(http://utmark.nina.no/portals/utmark/utmark_old/utgivels er/pub/2013-1/Skjeggedal_et_al_Utmark_1_2013_pv.html, accessed on 2018-02-19)

Smit HJ, Metzger MJ, Ewert F (2008) Spatial distribution of grassland productivity and land use in Europe. Agricultural Systems 98:208-219.

Smith B, Mark DM (2003) Do mountains exist? Towards an ontology of landforms. Environment and Planning B 30: 411-427. Sömme A, Langdalen E, Einevoll O, et al. (1965) Fjellbygd og feriefjell [Mountain communities or mountains for recreation]. Oslo: J. W. Cappelen.

Statistics Norway (2013) Statistical Yearbook 2013. Statistics Norway.

(http://www.ssb.no/en/befolkning/artikler-og-

publikasjoner/statistical-yearbook-of-norway-2013, accessed on 2018-02-19)

Tang G, Na J, Cheng W (2017) Progress of Digital Terrain Analysis on Regional Geomorphology in China. Acta Geodaedata et Cartographica Sinica 46(10): 1570-1591.

Tappeiner U, Borsdorf A, Tasser E (eds.) (2008) Alpenatlas Atlas des Alpes - Atlante dell Alpi - Atlas Alps - Mapping the Alps: Society - Economy - Environment. Heidelberg: Spektrum.

Thuiller W, Lavorel S, Araujo MB, et al. (2005) Climate change threats to plant diversity in Europe. Proceedings of the National Academy of Sciences of the United States of America 102:8245-8250.

UNEP (2014) Africa Mountains Atlas. Nairobi: United Nations Environment Programme.

UNESCO (2001) UNESCO in the Mountains of the World. Paris: UNESCO.

United Nations (2016) Sustainable Mountain Development. Resolution adopted by the General Assembly on 21 December 2016. Document A/RES/71/234. New York: United Nations.

United States Forest Service (1974) The Visual Management System. Agriculture. Handbook number 462. National Forest Landscape Management, vol.2, Chapter 1. Washington DC: US Government Printing Office.

van Eupen M, Metzger MJ, Perez-Soba M, et al. (2012) A rural typology for strategic European policies. Land Use Policy 29:473-482.

Voisey H, Beuermann C, Sverdrup LA, O'Riordan T (1996) The political significance of Local Agenda 21: the early stages of some European experience. Local Environment 1(1): 33-50.

von Dach S, Bachmann F, Borsdorf A, et al. (2016) Investing in Sustainable Mountain Development: Opportunities, Resources and Benefits. Bern: Centre for Development and Environment.

Zurick D, Pacheco J (2006) Illustrated Atlas of the Himalaya. Lexington: University of Kentucky Press. 